Cornell University

School of Industrial and Labor Relations

Center for Advanced Human Resource Studies
CAHRS at Cornell University $615 B$ Ives Hall

Ithaca, NY 14853-3901 USA

Tel. 607 255-9358

www.ilr.cornell.edu/CAHRS

Worhing Pheregehleg

\title{
Human Resource Practices and Organizational Commitment: A Deeper Examination
}

\author{
Patrick M. Wright
}

Rebecca R. Kehoe

Working Paper 07 - 15 


\title{
Human Resource Practices and Organizational Commitment: A Deeper Examination
}

\author{
Patrick M. Wright \\ and \\ Rebecca R. Kehoe \\ Department of Human Resource Studies \\ Center for Advanced Human Resource Studies (CAHRS) \\ School of ILR \\ Cornell University
}

December 2007

\section{http://www.ilr.cornell.edu/cahrs}

This paper has not undergone formal review or approval of the faculty of the ILR School. It is intended to make results of Center research available to others interested in preliminary form to encourage discussion and suggestions.

Most (if not all) of the CAHRS Working Papers are available for reading at the Catherwood Library. For information on what's available link to the Cornell Library Catalog:

http://catalog.library.cornell.edu if you wish. 


\begin{abstract}
This paper examines newer conceptualizations of HRM practices in the HR-Performance Relationship as well as newer conceptualizations of commitment. Juxtaposing these categories of HR practices and types of commitment provides a clearer theoretical rational for at least some ways that HR practices can influence organizational performance, be that positive or negative. Implications for research are then discussed.
\end{abstract}




\section{Human Resource Practices and Organizational Commitment: A Deeper Examination}

In a world increasingly characterized by globalization of product markets, the importance of human capital as a resource that can potentially provide competitive advantage has become more important. Because a firm's people are integral to its success, researchers interested in managing human capital have increasingly focused on HR practices as the levers through which firms might build the human capital that makes up resources and capabilities.

The fact that HR practices are related to firm performance has been well documented. Substantial research on the HR Practices performance relationship has demonstrated that HR practices are related to a number of firm performance measures such as Market Value (i.e., Tobin's Q) (Huselid, 1995), Return on Equity (Delery and Doty, 1996), and operational measures of performance (MacDuffie, 1995).

While the literature establishing an HR - performance relationship is substantial, what is lacking is empirical research examining the mechanisms through which this relationship works (Wright \& Gardner, 2003). Authors have referred to this as the "black box" problem, and many have called for more theory and research on the mediating mechanisms through which HR practices influence organizational performance (Becker and Gerhart, 1996).

A recent stream of thinking in this area has focused on the ways in which HR practices can elicit organizational commitment from employees, a construct which is argued to impact their motivation and desire to stay with the firm. However, recent advances have been made in the conceptualizations of both HR practices and organizational commitment. The purpose of this chapter is to provide a more detailed analysis of the link between HR practices and organizational commitment.

HR Practices and Organizational Commitment

A plethora of research exists examining the relationship between HR practices and performance. Such research has been conducted at the corporate (e.g., Huselid), business unit 
(e.g., Wright, Gardner, and Moynihan, 2003) and department level (e.g., ). Studies have examined multiple industries (e.g, Guthrie, 2001), within a single industry (e.g., MacDuffie, 1995) or even within a single corporation (Wright et al., 2003). While the observed effect sizes may differ across studies, qualitative reviews of this literature conclude that in almost all cases HR practices are found to be at least weakly related to performance (Boselie, Dietz, \& Boon, 2005; Wright, Gardner, Moynihan, \& Allen, 2005). This conclusion is supported by a recent meta-analysis concluding that the mean effect size for the HR - performance relationship is approximately .14 (Combs, Ketchen, Hall, \& Liu, 2006) implying that a one standard deviation increase in the use of high-performance work systems is associated with a $4.6 \%$ increase in return on assets. However, these empirical results tie HR practices to distal performance measures, without measuring more proximal outcomes.

In an early review of the HRM - performance literature, Dyer and Reeves (1995) posited 4 levels of outcomes of HRM practices-employee, organizational, financial, and marketsuggesting that the impact of HRM is likely to work outward through these levels. Employee outcomes consist of affective reactions such as satisfaction and commitment as well as behavioral reactions such as absenteeism and turnover. Organizational outcomes focus primarily on operational performance measures such as quality, productivity, and customer satisfaction. Financial outcomes, such as accounting profits, represent the next step in their causal chain. Finally, market outcomes consist of measures of the market value of firms based on stock price.

Becker et al. (1997) similarly argued that HRM practices operate most directly through employee skills, motivation, and work design, resulting in behavioral outcomes such as creativity, productivity, and discretionary effort, which are expected to work through operational and eventually through financial market outcomes. Hence, in order to assess the most immediate consequences of an HRM system, Becker et al. (1997) and Dyer and Reeves (1995) 
would suggest examining employee outcomes as they are predicted to be affected most directly.

More recently, Wright and Nishii (2006) offered further justification for examining outcomes of HRM below the organizational level. Specifically, these authors argued that, while most of the research to date has focused on the links between business level HRM practices and performance, the theoretical explanations offered for these relationships cross multiple levels of analysis, including individuals and job groups. For instance, the authors argued that HRM practices are largely implemented at the job group level (i.e., different jobs have different practices within a business unit). In addition, individuals within jobs may perceive and react (both affectively and behaviorally) differently to the same practices. These individual level reactions are both influenced by others in the job group and aggregated back to job group level outcomes. Finally, the performance of different job groups aggregates to affect business unit performance. Most importantly, however, Wright and Nishii noted that empirical research has focused only on the business unit linkages between practices and performance, and has virtually ignored the lower level mechanisms through which these linkages are purported to occur. Usually in discussions of the most proximal employee outcomes researchers mention or focus on the construct of organizational commitment.

Several researchers have examined the relationships between HRM practices and organizational commitment. For example, in an individual-level analysis, Paul and Anantharaman's (2004) study of software professionals showed that HRM practices had a significant positive relationship with organizational commitment. HRM systems have also been found to relate to commitment in samples of frontline employees from car rental, retail, and hospitality organizations in South America (Browning, 2006). Payne and Huffman (2005) found in a longitudinal study that organizational commitment mediated the relationship between mentoring, an HRM practice in the organization studied, and employee turnover over time. In a unit-level study, Wright, Gardner, \& Moynihan (2003) found a positive relationship between 
HRM practices and organizational commitment in a study of 50 business units from a large food service corporation.

Three basic themes emerge from much of the work tying HR practices to organizational commitment. First, these empirical and conceptual analyses focus on the concept of commitment, most often organizational commitment. Different conceptualizations of organizational commitment have been used in the literature. However, perhaps most important with regard to HRM practices is the concept of affective organizational commitment. This type of commitment refers to a positive affection toward the organization, reflected in a desire to see the organization succeed in its goals and a feeling of pride at being part of the organization (Cohen, 2003). While affective commitment to the firm may be one interesting conceptualization of commitment, it may also be a limited one. However, recent advances in examining the concept of commitment may lead to a more complex treatment of the construct (Klein, Morrow, and Brinsfield, in press).

Second, these attempts to examine the impact of HR practices on organizational commitment as a precursor to their impact on firm performance assume a simple, unidimensional, view of the HR practices. Normally the HR practices are measured with a multiitem scale (e.g., Wright et al., 2005). However, support for a more complex treatment of HR practices (relative to a unidimensional scale of "high commitment" practices) has been emerging in the SHRM literature (Gardner, Moynihan, \& Wright, 2007).

Finally, these treatments seem to assume and look for a universally positive set of relationships (HR practices positively impact commitment, and commitment positively impacts performance.) However, given the increasing complexity of conceptualizations of HR practices and commitment, such an assumption may be misleading. Juxtaposing these more complete and complex views of these constructs may lead us to a better understanding of how HR practices can positively (or negatively) impact firm performance. In order to do so, we will first examine the more recent conceptualizations of commitment, then the more recent 
conceptualizations of HR practices. These examinations will enable us to explore more complex ways in which these constructs might interact to impact firm performance.

\section{Current Conceptualizations of Organizational Commitment}

While the concept of commitment has a long history within the organizational literature (Becker, 1960) as frequently noted (e.g., Meyer \& Allen, 1991; Mowday, Porter, \& Steers, 1982; Reichers, 1985; Stebbins, 1970), commitment is inconsistently defined both within and across the various workplace commitments. This can be traced to several factors such as the different perspectives (e.g., economic, behavioral, psychological) from which researchers have studied commitment and the fact that several early writers defined commitment in multiple ways, as having multiple bases, or as being characterized by multiple indicators. For instance, Porter, Steers, Mowday and Boulian (1974) defined organizational commitment as the strength of an individual's identification with and involvement in a particular organization but then further stated that commitment is characterized by three factors (a) a belief in and acceptance of goals and values, (b) a willingness to exert effort, and (c) a strong desire to maintain membership.

In their review of the workplace commitment literature, Klein, Morrow and Brinsfield (in press) defined commitment as an individual's perception that they are bound to a given target. This definition depicts commitment as attachment rather than a force. They note that defining commitment as a perceived bond rather than a force more clearly (a) distinguishes commitment from its antecedents, (b) places commitment within the individual, and (c) recognizes the considerable variance in how individuals make sense of their environment (James \& Mazerolle, 2002; Weick, 1995). Their examination of commitment posits three aspects that are relevant to this paper: the elements of commitment, the outcomes of commitment, and competing commitments.

\section{Elements of Commitment}

They pose three distinct elements of commitment that need to be distinguished. First, the commitment target refers to the foci or object to which one is committed. An individual can 
be simultaneously committed to a wide variety of different targets but the commitment construct is essentially the same regardless of the target. In addition, we assert that different workplace targets are not facets or dimensions that underlie a global commitment construct in a hierarchical structure (e.g., Bagozzi \& Edwards, 1998). Research has demonstrated that employees can be highly committed to some workplace targets and not others (e.g., Becker \& Billings, 1993). Commitments to different workplace targets need not be highly related (e.g., one could be committed to their job, but not the organization), although spillover between different targets is possible (e.g., commitment to a supervisor can impact commitment to the organization).

Second, commitment strength reflects the intensity or degree to which someone is committed to a target. According to Klein et al's (in press) conceptualization, commitment is (a) dynamic but can be relatively stable, (b) not necessarily consciously perceived or intentional, and (c) socially constructed within the individual. Unlike a multidimensional view, commitment strength is singular: one can be committed to multiple targets but commitment strength has the same singular meaning regardless of the target.

Third, commitment rationales are the multiple possible self-explanations a person can hold for their commitment to a given target, i.e., how one makes sense of or rationalizes their commitment. According to Klein et al. (in press), an individual can have multiple rationales for a particular commitment, those rationales can change over time, and may be conscious or unconscious. Commitment rationales are in some ways analogous to attributions. Attributions are not the performance itself but are the individual's self-explanation for why they performed the way they did (Weiner, 1985). Similar to attributions, commitment rationales may not reflect the "objective" antecedents of commitment, yet those rationales still determine the individual's reactions and responses.

It is clear that there can be multiple rationales, but the exact number and structure of distinct rationales is indeterminate from the literature. Although research has generally 
supported Allen and Meyer's (1990) framework there have been numerous exceptions supporting alternative models (Meyer \& Herscovitch, 2001). Furthermore, the various bases of commitment underlying most frameworks are rooted in research conducted nearly fifty years ago. Just as Brief (1998) questioned whether the facets of job satisfaction might have changed in relevance over time, the types and importance of rationales for workplace commitments have likely changed given the considerable changes in the nature of work and the employment relationship. Determining the precise configuration of distinct commitment rationales is both a conceptual and an empirical question that cannot be resolved here.

\section{Commitment Outcomes}

The first category of commitment outcomes identified by Klein et al. concerned affect, or the emotions, positive or negative, that one feels towards a target. They argue that the nature of the affective response depends upon the commitment rationale.

The second general outcome category they identified was continuance, or the unwillingness to withdraw from the target. Both intentions and behaviors are included in this category. Continuance is not necessarily indefinite but instead implies the expected duration of the association. For instance, with the organization as the target, commitment has been shown to relate to turnover, absenteeism, and tardiness (e.g., Mathieu \& Zajac, 1990).

Finally, motivation outcomes include both the willingness to exert effort in support of the target and persistence in maintaining that effort over time. Commitment to an organization involves a willingness to exert effort in support of that organization, group, or person. The specific nature of the effort (e.g., in-role vs. extra-role, minimal vs. optimal) depends on both commitment rationales and strength.

\section{Competing Commitments}

A final contribution that Klein et al make is specifically recognizing multiple commitments. They note that individuals have multiple commitments within the workplace (e.g., Simon, Smithburg, \& Thompson, 1950) as well as to other institutions outside of work (e.g., 
family, professional and social organizations, political parties, religious organizations) (Morrow, 1983; Reichers, 1985). While the capacity for an individual to form commitments across targets may be boundless, there are limits on an individual's resources (e.g., time, emotion, attention) (Kanfer \& Ackerman, 1989; Naylor, Pritchard, \& Ilgen, 1980). Multiple commitments need not be in conflict (Randall, 1988) particularly when the different targets have compatible demands (Angle \& Perry, 1986). However, competing commitments can both inhibit commitment strength or impede a commitment leading to the expected consequences.

\section{Implications}

These elements, outcomes, and competing commitments ideas have implications for how HR practices might impact commitment. First, while most of the research has focused on the organization as the target of commitment, one could conceive of other targets both that might be impacted by HR practices and that might subsequently impact performance. For instance, commitment to goals, to the job, to the supervisor, or to the workgroup might play as significant a role as commitment to the organization. This suggests a broader view of the potential commitments that could be impacted by HR practices and that might be related to firm performance.

Second, the concept of rationales recognizes that people make sense of the HR practices they experience, and this sensemaking may influence their response in terms of commitment. For instance, Wright and Nishii (2006) developed a multilevel model of the impact of HR practices on performance and noted that individuals must perceive, interpret, and react to those practices, and that information processing will be largely influenced by their past experiences. For instance, individuals who have worked for employers that attempted to exploit them might interpret a new employer's gain sharing or profit sharing program as simply one more way to exploit the workforce. On the other hand, an employee who came from a positive previous work experience might interpret the same programs as an altruistic way in which the firm wants to share its success with employees. Similarly, with regard to commitment, one 
highly paid employee may attribute his/her desire to remain as a function of a lack of alternatives where they could make as much money. Thus, the outcomes may be affective resentment, high continuance, and low motivation. On the other hand, another might feel obligated to stay because the firm has chosen to pay them so well. His/her outcomes might be affective appreciation, high continuance, and high motivation. Clearly the attribution for commitment can vary within the same HR practice experience.

Finally, multiple commitments implies that even when HR practices elicit the organizational commitment desired, the outcomes may not be observed if they conflict with other commitments. An individual can be highly committed to an organization, but a commitment to a family may supersede the commitment to the firm. For instance, an EVPHR at a brand name firm recently resigned his position. When asked about it, he said that it was hard because he had finally found the company with the right values and a CEO who had the right personality to create a job he loved. However, due to a family tragedy, he needed to move his family away; in essence he described a family commitment that got in the way of his organizational commitment.

Having examined commitment, we will now turn our attention to conceptualizations of HR practices.

\section{HRM Practice Bundles and Performance}

Most SHRM scholars agree that systems or bundles of HRM practices are required for organizations to achieve sustained performance results (Delery \& Shaw, 2001; MacDuffie, 1995). HRM practice bundles include generally complete sets of mutually reinforcing or synergistic practices (Dyer \& Reeves, 1995).

SHRM scholars have argued that systems of HRM practices are more likely to drive sustainable performance outcomes than are individual practices. For example, Dyer and Reeves (1995) argued that employee performance is likely to be greatest when its two components, ability and motivation, are influenced in multiple, redundant ways. Specifically, the 
authors suggested that performance is likely to be maximized when several reinforcing practices-such as rigorous selection mechanisms and ample training opportunities-elicit required employee skills, and many incentives-such as peer pressure to perform and monetary and non-monetary rewards_-increase employee motivation. Additionally, Delery and Shaw (2001) noted that, while certain individual HRM practices are viewed as superior to others, a single superior HRM practice without other supporting practices in the system is inadequate as a driver of sustainable performance outcomes. Rather, the authors argue, individual "best practices" must be part of a larger, universally superior HRM system to support sustainable success.

Researchers have consistently demonstrated an association between what have been variously called High Performance Work Systems, High Commitment HRM models, and High Involvement HRM systems and firm financial performance. While the specific HR practices included in these commitment-based systems have varied across studies, these "best practice" models share certain defining characteristics. In particular, these models typically include performance-based compensation schemes which reward group and organization-level performance outcomes and provide opportunities for employees to participate in organizational decision making (Arthur, 1992). Employee development, reward, and retention plans encourage long-term employment relationships and often promote strong internal labor markets, regular team-focused assignments, and an emphasis on firm-specific knowledge (Arthur, 1992; Tsui, Pearce, Porter, \& Tripoli, 1997). Past research in HR practices has often operationalized the HR system as a single scale of HR practices (Guthrie, 2001, Datta Guthrie \& Wright, 2001) or sometimes an empirically derived multidimensional scale (e.g., Huselid, 1995).

However, a number of SHRM researchers have noted that human resource systems can be described along three common dimensions \{Appelbaum et al. 2000; Delery 1998; Dyer \& Holder 1988; Lepak et al., 2005\}. First is the degree of investment in HR practices intended to improve the knowledge, skills and abilities of the companies' employees. These include 
recruiting, training, selection, socialization, and any other practice functioning to enhance the workplace competencies of the employees. Such practices seek to build specific relevant skills, or increase the level of those skills among the focal human capital group. With regard to capabilities, this category of practices can aim to ensure that the organization has the skills and skill levels required by those employee key to the execution of business processes.

The second dimension is the degree of investment in HR practices functioning to motivate employee behavior. In general, HR practices can seek to elicit task related behavior (that necessary to perform the basic job), encourage employees to exhibit discretionary behavior (i.e., go outside the expected job behaviors to positively impact organizational effectiveness), or to discourage counterproductive behavior (actions that negatively impact the firm such as theft, sabotage, etc.) Practices such as incentive pay plans, performance bonuses, gainsharing, and performance management systems primarily aim at managing employee behavior. Because business processes require certain behaviors of key employee groups, one focus of the HR system has to be on eliciting the positive behaviors and inhibiting the negative ones.

Finally, HR practices function to provide opportunities to participate in substantive decision-making regarding work and organizational outcomes. These include such practices as quality circles, suggestion systems, granting discretion and authority on the job, information sharing about the service or production process, and opportunities to communicate with employees and managers in other workgroups. This is one area where differentiation may be seen across a variety of business processes. For instance, Starbucks, the outstanding coffee retailer, seeks operational excellence in the processes used to make a cup of coffee. A number of training programs teach specific procedures for exactly how much of each ingredient should be used, in what order, etc. In these processes there is little opportunity for employees to deviate from the prescribed behavior. However, in terms of serving customers, Starbucks employees have great latitude to deviate from prescribed behavior, or share ideas and 
suggestions for certain aspects of the operation.

While the practice can be subcategorized within the AMO framework, Lepak et al., (2005) note that the framework does not preclude overlap among the practices. For instance, training programs primarily may aim at building the requisite skill base, but may also communicate a commitment to the employee that elicits motivation as well. Similarly, participation programs provide opportunity, but may also help build the knowledge and motivation of employees.

This more complex treatment of HR practices seems both theoretically justified and empirically more fruitful. For instance, Gardner, Moynihan, and Wright (2007) found that the motivation and opportunity focused bundles of HR practices positively related to affective commitment and negatively related to turnover. However, skill oriented practices were unrelated to affective commitment and positively related to turnover. Adding complexity to the HR practice measures provides a deeper understanding of their impact.

Each of the three dimensions of HR practices can be expected to have unique effects on commitment. Motivation enhancing practices should positively influence commitment, and result in motivational outcomes. Consistent with the perceived organizational support arguments, incentives and other rewards-for-performance practices signal a positive valuation of employee efforts thus increasing reciprocal commitment (Meyer and Allen, 1997; Rhoades et al., 2001). Additionally, Klein's (1987) extrinsic satisfaction model suggests that financial rewards designed to increase commitment to work outcomes align employee interests with the organizations resulting in greater commitment to the organization. However, these practices may not impact continuance outcomes unless the pay is at a level that would require employees to take a pay cut if they left.

Secondly, empowerment enhancing practices are expected to have a positive impact on organizational commitment, and probably impact the affect, motivation, and continuance outcomes. Organizations that allow employee input into decisions, share information, and treat 
employees with respect strengthen shared perceptions of congruence between employee and organizational values, integrate employees into the life of the firm, and increases employees' identification with the firm thus enhancing commitment (Arthur, 1994; Long, 1980; Meyer and Herscovitch, 2001). Additionally, the teamwork and social interactions inherent in empowering HR practices function to accelerate the A-S-A process while simultaneously creating a sense of community, thus strengthening the forces of social cohesion among group members and thus the commitment to the organization (Morrison, 2002; Osterman, 1995).

Finally, skill enhancing practices may have no, or even a negative impact on commitment, particularly on the continuance outcomes. While training investments may increase employees' perceptions that the organization values their current and future contributions and thus their level of commitment (Meyer and Allen, 1997; Tannenbaum et al., 1991), they also may increase the marketability of those employees. Human capital theory and the March and Simon (1958) ease-of-movement framework suggest that HR practices that improve the knowledge, skills, and abilities of the employees flowing into and within the organization would result in increased aggregate voluntary turnover (Benson, et al. 2004; Oatey 1970; Williamson, et al. 1975). Trevor (2001) defined the set of individual attributes that enhance employees' ability to secure employment outside of their employing organizations as 'movement capital.' These attributes include task specific abilities, productivity, education, cognitive abilities, and general skills. Trevor's (2001) research complements March and Simon's (1958) work on ease of movement by demonstrating that employees with greater movement capital are more likely to leave their employing organization for another employer.

However, even the AMO framework may be deficient, mainly in that it largely ignores certain practices, particularly those that do not fit well within the framework. For instance, stock options, a compensation scheme that has increased in popularity over the past few decades (particularly in the U.S.) may encourage recipients to stay in the short term as departure results in forfeiting the options. However, after the options have vested, and particularly if they have 
resulted in substantial wealth accrual, they may enable the recipient the ability to leave the firm. In fact, during the 1990's Microsoft found a disproportionate level of turnover among employees who had been with the company between 7 and 10 years, the time at which they were able to exercise a large number (and value) of options.

In addition, while many of the HR practice scales contain items such as "promotion from within" policies, such policies can vary substantially. For instance, unionized, seniority based pay and promotion systems would qualify as a "promote from within" policy, but such policies may have very different effects on commitment and commitment outcomes. One need look no further that the U.S. Airline industry, where seniority based systems virtually preclude movement from one airline to another. Having engaged in cutbacks in salaries and benefits, these airlines have created workforces with commitment outcomes of low affect, low motivation, but unfortunately, high continuance.

\section{Implications and Conclusions}

As noted previously, researchers on the HR and firm performance relationship have increasingly called for research on the "black box," or more proximal mediators of this relationship. Much attention within this realm has focused on organizational commitment as one such potential mediator. However, recent conceptualizations of HR practices and commitment call for a more nuanced approach to studying this relationship.

Klein et al.'s (in press) conceptualization of commitment as an individual's perception that they are bound to a given target certainly focuses on the psychological process through which employees form such perceptions. Bowen and Ostroff (2004) argued that HR practices serve as communications mechanisms to employees, and these communications must be interpreted through each individual's personal lens (Wright \& Nishii, 2006). Again, the concept of rationales, or attributions focuses attention on individual differences in reactions to the same sets of HR practices.

Separating the commitment construct from the outcomes of affect, continuance, and 
motivation outcomes may seem to be theoretical nitpicking. However, it focuses research attention on the variety of outcomes that can be observed, and considering these outcomes with different HR practice sub-bundles leads to better understanding of the impact that each subbundle can have. Rather than focus on laundry lists of "high commitment" or "high performance" HR practices, the AMO approach enables a more theoretically specific understanding of the relationships between HR practices and organizational commitment.

In addition, as noted before, much of the previous research focused only on the affective commitment measure, which tended to include items that might reflect continuance commitment (e.g. "I would turn down a job with more money to stay with this organization.") This newer conceptualization of commitment might suggest developing more specific and more comprehensive measures of commitment outcomes to ensure that each category is adequately covered.

Finally, this analysis suggests that in order to truly understand how HR practices impact firm performance, we must measure all the practices, not just those we think are "high commitment" or "high performance" ones. While the AMO framework provides more specificity than the unidimensional scale (Delery, 1998; Delery and Shaw, 2001; Lepak et al., 2005) it still seems to only assess practices that are deemed to have strong positive outcomes. However, many practices exist that might not meet this criteria but may still impact performance. It would behoove the field to broaden our measures to include such practices. 


\section{References}

Appelbaum, E., Bailey, T., Berg, P. and Kallenberg, A.L. 2000. Manufacturing advantage. Why high-performance work systems pay off. New York. Cornell University Press.

Allen, N. J., \& Meyer, J. P. 1990. The measurement and antecedents of affective, continuance and normative commitment to the organization. Journal of Occupational Psychology, 63, 118.

Angle, H. L., \& Perry, J. L. 1986. Dual commitment and labor-management relationship climates. Academy of Management Journal, 29, 31-50.

Arthur, J. B. 1992. The link between business strategy and industrial relations systems in American steel minimills. Industrial and Labor Relations Review, 45, 488-506.

Arthur, J. B. 1994. Effects of human resource systems on manufacturing performance and turnover. Academy of Management Journal, 37, 670-687.

Bagozzi, R. P., \& Edwards, J. R. 1998. A general approach for representing constructs in organizational research. Organizational Research Methods, 1, 45-87.

Becker, H. S. 1960. Notes on the concept of commitment. American Journal of Sociology, 66, $32-40$.

Becker, T. E., \& Billings, R. S. 1993. Profiles of commitment: An empirical test. Journal of Organizational Behavior, 14, 177-190.

Becker, B., \& Gerhart, B. 1996. The impact of human resource management on organizational performance: Progress and prospects. Academy of Management Joumal, 39, 779-801.

Becker, B., Huselid, M., Pinckus, P. \& Spratt, M. 1997. HR as a source of shareholder value: Research and recommendations. Human Resource Management, 36, 39-48.

Benson, G. S., Finegold, D., \& Mohrman, S. A. You paid for the skills, now keep them: tuition reimbursement and voluntary turnover. Academy of Management Journal, 47, 315-331.

Boselie, P., Dietz, G. and Boon, C. 2005. Commonalities and contradictions in HRM and performance research. Human Resource Management Journal, 15, 67-94.

Bowen, D. E., \& Ostroff, C. 2004. Understanding HRM-firm performance linkages: The role of "strength" of the HRM system. Academy of Management Joumal, 29, 203-221.

Brief, A. P. 1998. Attitudes in and around organizations. Thousand Oaks: CA. Sage.

Browning, V. 2006. The relationship between HRM practices and service behaviour in South African service organizations. International Journal of Human Resource Management, 17, $1321-1338$.

Cohen, A. 2003. Multiple commitments in the workplace. Mahwah, NJ: Lawrence Erlbaum Associates.

Combs, J., Liu, Y., Hall, A., \& Ketchen, D. 2006. How much do high performance work practices matter? A meta-analysis of their effects on organizational performance. Personnel Psychology, 59, 501-528

Datta, D. K., Guthrie, J. P., \& Wright, P. M. 2005. HRM and labor productivity: Does industry matter? Academy of Management Joumal, 48, 135-145.

Delery, J. E. 1998. Issues of fit in strategic human resource management: Implications for research. Human Resource Management Review, 8, 289-309.

Delery, J.E. and Doty, D.H. 1996. Modes of theorizing in strategic human resource management: tests of universalistic, contingency, and configurational performance predictions. Academy of Management Journal, 39, 802-835.

Delery, J. E., \& Shaw, J. D. 2001. The strategic management of people in work organizations: Review, synthesis, and extension. Research in Personnel and Human Resource Management, 20, 165-197.

Dyer, L., \& Holder, G. W. 1988. A strategic perspective of human resource management. In L. Dyer (Ed.), Human Resource Management: Evolving Roles and Responsibilities : 1.1-1.46. Washington, D.C.: The Bureau of National Affairs.

Dyer, L \& Reeves, T. 1995. HR strategies and firm performance: What do we know and where 
do we need to go. Intemational Joumal of Human Resource Management, 6, 656-670. Gardner, T., Moynihan, L., and Wright, P. 2007. The Influence of Human Resource Practices and Collective Affective Organizational Commitment on Aggregate Voluntary Turnover. CAHRS Working Paper, Cornell University. 
Guthrie, J.P. 2001. High-involvement work practices, turnover, and productivity: Evidence from New Zealand. Academy of Management Journal, 44, 180-190.

Huselid, M.A. 1995. The impact of human resource management practices on turnover, productivity, and corporate financial performance. Academy of Management Journal, 38, 635-672.

James, L. \& Mazerolle, M. 2002. Personality at work. Beverly Hills, CA: Sage.

Kanfer, R., \& Ackerman, P. L. 1989. Motivation and cognitive abilities: An integrative/aptitude treatment interaction approach to skill acquisition. Journal of Applied Psychology, 74, 657690.

Klein, H., Morrow, J., and Brinsfield, C., (in press), Understanding commitment in the workplace: Differentiating commitment strength, rationales and targets. In, H J. Klein, T. E. Becker, and J. P. Meyer, (Eds) Commitment in Organizations: Accumulated Wisdom and New Directions Forthcoming Book for the SIOP Frontiers Series, Lawrence Erlbaum.

Lepak, D.P., Bartol, K.M., \& Erhardt, N. 2005. A contingency framework of the delivery of HR practices. Human Resource Management Review, 15, 139-159.

Long, R. L. 1980. Job attitudes and organizational performance under employee ownership. Academy of Management Joumal, 23, 726-737.

MacDuffie, J.P. 1995. Human resource bundles and manufacturing performance: Organizational logic and flexible systems in the world auto industry. Industrial and Labor Relations Review, 48, 197-221.

March, J., \& Simon, H. 1958. Organizations. New York: Willey.

Mathieu, J.E. \& Zajac, D.M. 1990. A review and meta-analysis of the antecedents, correlates, and consequences of organizational commitment. Psychological Bulletin, 108, 171-194.

Meyer, J.P. \& Allen, N.J. 1991. A three-component conceptualization of organizational commitment. Human Resource Management Review, 1, 61- 89.

Meyer, J. P. and Allen, N. J. 1997. Commitment in the workplace: Theory, research, and application. Thousand Oaks, CA: Sage.

Meyer, J. P., \& Herscovitch, L. 2001. Commitment in the workplace: Toward a general model. Human Resource Management Review, 11, 299-326.

Morrison, E. W. 2002. Newcomers' relationships: The role of social network ties during socialization. Academy of Management Journal, 45, 1149-1160.

Morrow, P. C. 1983. Concept redundancy in organizational research: The case of work commitment. Academy of Management Review, 8, 486-500.

Mowday, R.T., Porter, L.W., \& Steers, R.M. 1982. Employee-organizational linkages. New York: Academic Press.

Naylor, J. D., Pritchard, R. D., \& Ilgen, D. R. 1980. A theory of behavior in organizations. New York: Academic Press.

Oatey M. 1970. The economics of training with respect to the firm. British Journal of Industrial Relations, 8, 1-21.

Osterman, P. 1995. Work/Family programs and the employment relationship. Administrative Science Quarterty, 40, 681-700.

Paul, A. K. \& Anantharaman, R. N. 2004. Influence of HRM practices on organizational commitment: A study among software professionals in India. Human Resource Development Quarterty, 15, 77-88.

Payne, S. C. and Huffman, A. H. 2005. A longitudinal examination of the influence of mentoring on organizational commitment and turnover. Academy of Management Journal, 48, 158-168.

Porter, L. W., Steers, R. M., Mowday, R. T., \& Boulin, P. V. 1974. Organizational commitment, job satisfactions, and turnover among psychiatric technicians. Journal of Applied Psychology, 59, 603-609.

Randall, D. M. 1988. Multiple roles and organizational commitment. Journal of Organizational Behavior, 9, 309-317.

Reichers, A. E. 1985. A review and reconceptualization of organizational commitment. Academy 
of Management Review, 10, 465-476.

Rhoades, L, Eisenberg, R., \& Armeli, S. 2001. Affective commitment to the organization: the contribution of perceived organizational support. Journal of Applied Psychology, 86, 825-836.

Simon, H. A., Smithburg, D. W., \& Thompson, V. A. 1950. Public Administration. New York: Knopf.

Stebbins, R. A. 1970. On misunderstanding the concept of commitment: A theoretical clarification. Social Forces, 48, 526-529.

Tannenbaum, S. I., Mathieu, J. E., Salas, E., \& Bowers, J. A. 1991. Meeting training expectations: The influence of training fulfillment on the development of commitment, self efficacy, and motivation. Journal of Applied Psychology, 76, 759-769.

Trevor, C. O. 2001. Interactions among actual ease-of-movement determinants and job satisfaction in the prediction of voluntary turnover. Academy of Management Journal, 44, 621-638.

Truss, C. 1997. Complexities and controversies in linking HRM with organizational outcomes. Journal of Management Studies, 38, 1121-1149.

Tsui, A. S., Pearce, J. L., Porter, L. W., \& Tripoli, A. M. 1997. Alternative approaches to the employee-organization relationship: Does investment in employees pay off? Academy of Management Journal, 40, 1089-1121.

Weick, K. E. 1995. Sensemaking in organizations. In D. Whetten (Series Ed.), Foundations for organizational science. Thousand Oaks, CA: Sage.

Weiner, B. 1985. An attributional theory of achievement motivation and emotion. Psychological Review, 92, 548-573.

Williamson, O. E., Wachter, M. L., \& Harris, J. E. 1975. Understanding the employment relation: The analysis of idiosyncratic exchange. Bell Journal of Economics, 6, 250-278.

Wright, P. M. \& Gardner, T. M. 2003. The human resource-firm performance relationship: methodological and theoretical challenges. In D. Holman, T. D. Wall, C. W. Clegg, P. Sparrow, \& A. Howard (Eds.), The new workplace: A guide to the human impact of modem working practices (pp. 311-328). West Sussex, UK: Wiley.

Wright, P.M., Gardner, T.M. and Moynihan, L.M. 2003. 'The impact of HR practices on the performance of business'. Human Resource Management Journal, 13, 21-36.

Wright, P.M., Gardner, T.M., Moynihan, L.M. and Allen, M.R. 2005. The relationship between HR practices and firm performance: Examining causal order. Personnel Psychology, 58, 409446.

Wright, P.M. and Nishii, L.H. 2006. Strategic HRM and organizational behaviour: Integrating multiple levels of analysis. Working paper. Cornell University. 